\title{
Applying an international CAPM to herding behaviour model for integrated stock markets
}

\author{
Najmudin \\ Faculty of Economics and Business, Universitas Diponegoro, \\ Indonesia \\ Faculty of Economics and Business, Universitas Jenderal Soedirman, \\ Indonesia \\ kuliab_najmudin@yahoo.co.id
}

\section{Diana Hashim Syarif}

Faculty of Economics and Business, Universitas Diponegoro,

Indonesia

dheeanahasheem@yahoo.com

\section{Sugeng Wahyudi}

Faculty of Economics and Business, Universitas Diponegoro,

Indonesia

sug_w@yahoo.com

\section{Harjum Muharam}

Faculty of Economics and Business, Universitas Diponegoro,

Indonesia

hardjum@gmail.com

Abstract. Development of financial globalization in the form of stock market integration experiences a trend which is getting stronger. The analysis models in the field of finance and investments should be able to adjust to these developments. This adjustment includes the models used to detect the existence of herding behavior. All this time, the herding behavior model of individual stocks towards market consensus has been referring to CAPM theory. The basic assumption of CAPM is that financial assets at a domestic stock market are segmented from the financial assets' movement at the global market. Therefore, this paper aims to provide an alternative view in the form of an international herding model that should be applied in the context of an integrated stock market. The model was created with reference to the international CAPM. This paper combined ICAPM method and international CSAD model to identify herding for eight stock markets, the sample period being from January 2003 to December 2016. The result found that for segmented stock markets, represented by China
Received: September, 2017

1st Revision:

October, 2017

Accepted:

November, 2017

DOI:

$10.14254 / 2071$ $8330.2017 / 10-4 / 3$ 
and the Philippines, herding happened for both overall the sample period and the market crisis period. In addition, for the integrated stock markets, represented by Indonesia, Japan, Malaysia, Singapore, Thailand, and the UK, herding behavior was only found during the market crisis period. Therefore, classification of market integrations should be considered in assessing the herding behaviour at stock markets.

Keywords: herding behavior, market integration, international CAPM.

JEL Classification: G11, G12, G15, F36

\section{INTRODUCTION}

The whole period of the global financial crisis clearly shows that stock prices at the market deviate from their fundamental value (Economou et al., 2011). A well-documented behavior existing in such extreme market conditions is herding, which is defined as joint imitation that leads to the centralization of action (Hirshleifer \& Teoh, 2003; Welch, 2000). The constraints of liquidity, asymmetric information, limited arbitrage and other frictions are commonly used by irresponsible people when such phenomenon occurs (Brunnermeier, 2001; Shleifer, 2000).

In addition, Mobarek et al. (2014) state that as a result of a widespread crisis, herding behavior at financial market has emerged as a relatively popular topic in financial literature. The researchers assert that herding behavior by market participants exacerbates market volatility and makes market instable. The empirical findings show that the existence of herding can exacerbate return volatility (Blasco et al., 2012; Demirer \& Kutan, 2006; Di Guilmi et al., 2014), however, there are also studies proving that herding behavior has positive effect on return volatility (Messis \& Zapranis, 2014; Venezia et al., 2011).

Researchers investigating empirically the existence of herding behavior reach different conclusions. For example, herding behavior was found in the UK (Chiang \& Zheng, 2010), China (Chiang \& Zheng, 2010; Lao \& Singh, 2011; Tan et al., 2008), Hong Kong (Chiang \& Zheng, 2010; Lam \& Qiao, 2015), Germany, France (Chiang \& Zheng, 2010), Italy and Greece (Economou et al., 2011; Messis \& Zapranis, 2014). In contrast, this type of behavior was not found by some other researchers studying exactly the same markets, i.e., the UK (Galariotis et al., 2015), China (Demirer \& Kutan, 2006), Hong Kong (Chang et al., 2000), Germany, France, Italy, and Greece (Mobarek et al., 2014).

A number of empirical studies on the integration of stock markets has reached quite varying results. The previous researches suggest that most of the observed stock markets are classified as integrated or at least have a tendency of intensified integration (Click \& Plummer, 2005; Diamandis, 2008; Neaime, 2012; Chien et al., 2015; Pietrzak et al., 2017). For example, Click and Plummer (2005) reported that the stock markets of ASEAN-5 (Indonesia, Malaysia, the Philippines, Singapore, and Thailand) countries are integrated. Diamandis (2008), using the dynamic conditional correlation (DCC) method, reported that shortterm interdependence between Latin America stock markets and developed stock markets increased during the 1997-1998 financial crisis in Asia, Latin America, and Russia. A more recent study by Pietrzak et al. (2017) found the interdependences among Poland, Czech Republic, Hungary, Austria, and Germany markets. The existing researches, however, still generally impose the herding behavior model of individual stocks towards market consensus by ignoring the type of stock markets.

The CSAD (cross-sectional absolute deviation of returns) model, which is the popular measure of herding model in previous literature, consists of local stock market return $\left(\mathrm{R}_{\mathrm{m}}\right)$ as presented in Eq. 13. This model is derived from CAPM (capital asset pricing model) theory assuming that stock markets are 
segmented. CAPM states that the only factor or risk affecting the price of an asset is market portfolio or national stock market return. When a researcher is confident about this assumption and yet the facts do not prove the same, then the herding model use may become inappropriate. As a consequence, findings of such research become doubtful. Therefore, herding model measured by CSAD model from the existing studies needs to be reviewed using other well-grounded theories.

To prove this issue, we observed China, ASEAN-5, Japan, and the UK stock markets. China and the ASEAN experience significant growth on domestic market capitalization. China stock market is the second largest in the world with market capitalization volume of US $\$ 7.3$ trillion. While stock markets in the ASEAN member countries are still smaller, it did not rule out becoming a market that transcends country boundaries if integration turns out to be really successful. Total market capitalization for ASEAN-5 stock markets region was US $\$ 2.1$ trillion in 2016. China and ASEAN member countries governments have agreed on intergovernmental financial transactions through financial markets deregulation and capital account liberalization, and this has made their stock markets' liberalization develop rapidly. In addition, the UK is the largest stock exchange in Europe with market capitalization of US $\$ 3.5$ trillion, while Japan is one of the central stock market in Asia with market capitalization of US\$4.9 Trillion (World Bank, 2017).

\section{LITERATURE REVIEW}

Herding behavior in the economics field was first mentioned in The General Theory by John Maynard Keynes (1936) which was called as animal spirit. Keynes identified sociological factors driving the investors' trade, for example the socially propelled conventions that encourage investors to do what others do (Baddeley, 2010). Herding is described by resorting to the metaphors of Beauty Contest and Delicious Apple. It relates to ignoring the private information and beliefs of an investor by joining collectively in trade of group, even the trade is not supported by valid information. The investors may only imitate and follow the action of a peer of investors (Litimi et al., 2016). Such imitation or herd originates from the habit of animals and has been documented among birds, fish, and mammals in foraging and diet choices (Hirshleifer $\&$ Teoh, 2003).

Banerjee (1992) defines herding as everyone who is doing what others are doing even when their private information indicates to do anything else. Bikhchandani et al. (1992) suggest that herding in the analysis of market behavior is defined as the behavior of individual who follows the decision or action of others first without knowing what information underlying the initial individual to behave (information cascade). In the most common definition, herding behavior occurs if the action of an individual is not dependent on the signal of private information owned. The form of that behavior is expressed as mass behavior pattern. Such behavior is a form of individual interaction with each other which on regular basis tends to think and behave in the same way (Shiller, 1995). Furthermore, Christie and Huang (1995) suggest that herding behavior is more visible during the turmoil period or market stress compared to a stable period. Generally, the behavior occurs when a decision made by an individual is covered by the condition of information imperfection and uncertainty of major decision environment (Alchian, 1950). In the stock market, herding is an investor's transaction activity by following the decisions or actions of other market participants and joining in the same trade direction without using his/her own information and analysis.

There are two main forms of herding, the irrational and the rational. From the irrational perspective, Christie and Huang (1995) define herding as individual investors who suppress their own beliefs and base their investment decisions on the collective actions of the market, despite the fact that they do not agree with the estimated results. Chang et al. (2000) consider herding as irrational market behavior when investors ignore previous beliefs and blindly imitate decisions of other investors. From the rational perspective, herding occurs due to the belief of low-ability managers follow the actions of more senior investors, so they 
wholeheartedly ignore their private information because they believe the decisions of other investors are better in absorbing information. By doing so, they can maintain their reputation capital in the market (Devenow \& Welch, 1996).

CAPM introduced by Sharpe (1964), Lintner (1965) and Mossin (1966) is a model for determining the price of a financial asset in the equilibrium condition. In this condition, the rate of return required by investor for a financial asset is affected by its risk. The risk considered is a systematic risk represented by beta. CAPM is established based on the model of portfolio selection developed by Harry Markowitz in 1959 (Fama \& French, 2004). CAPM can be summarized in the following statements. Diversification is a natural way to reduce risk; the risk that can be diversified is called as unsystematic risk; the risk that cannot be diversified is called as systematic risk; investor in a portfolio is exposed to systematic risk so that it requires compensation for the risk; market model provides a way to measure the systematic risk and this measure is called beta; the beta reflects an asset return $\left(\mathrm{R}_{\mathrm{i}}\right)$ correlated with the market portfolio return $\left(\mathrm{R}_{\mathrm{m}}\right)$.

CAPM describes a relationship between expected return in a risky asset $E\left(\mathrm{R}_{\mathrm{i}}\right)$ and its beta. Excess return on a certain asset (the difference between the return and risk-free asset) must be proportional to the excess return on the market portfolio. The CAPM is formulated as follows:

$$
\begin{aligned}
& E\left(R_{i}\right)-R_{f}=\beta_{i}\left[E\left(R_{m}\right)-R_{f}\right] \\
& E\left(R_{i}\right)=R_{f}+\beta_{i}\left[E\left(R_{m}\right)-R_{f}\right]
\end{aligned}
$$

Where $\mathrm{E}\left(\mathrm{R}_{\mathrm{i}}\right)$ is the expected return on asset $\mathrm{i} ; \mathrm{E}\left(\mathrm{R}_{\mathrm{m}}\right)$ is the expected return on market portfolio; $\mathrm{R}_{\mathrm{f}}$ is risk free return; $\beta_{i}$ is beta or systematic risk and $\beta_{i}=\operatorname{cov}\left(R_{i}, R_{m}\right) / \operatorname{var}\left(R_{m}\right)$.

Market model can be used to estimate the magnitude of beta. The equation of market model is expressed as follows:

$$
\mathrm{R}_{\mathrm{i}}=\alpha_{\mathrm{i}}+\beta_{\mathrm{i}} \mathrm{R}_{\mathrm{m}}+\varepsilon_{\mathrm{i}}
$$

Where $R_{i}$ is the rate of return on asset $i$; $R_{m}$ is the rate of return on market index; $\alpha_{i}$ is the intercept; $\beta_{i}$ is the slope or beta; $\varepsilon_{i}$ is a random error.

The pioneers of international CAPM theory are Solnik (1974b), Merton (1980), Stulz (1981), Adler and Dumas (1983) and Harvey (1991). For example, Solnik (1974b) states that CAPM developed by Sharpe, Lintner and Mossin is the basis for a new theory of stock market. The applied model in the single national market indicates that all investors can make their investment decisions by selecting their portfolio of two funds; they are market portfolio and the risk-free assets. Moreover, the model predicts that expected extra return from holding an asset is proportional to the covariance of its return with the market portfolio.

Since the 1960s, different capital asset pricing models are developed to review the question of market integration. A number of theoretical models explicitly assume full segmentation of the stock market, for example by Sharpe (1964); Lintner (1965); Ross (1976). While other model focuses on the relationship of theoretical asset price in the international context and assumes that national stock market is perfectly integrated, for example in study of Adler and Dumas (1983).

CAPM proposed by Sharpe (1964) and Lintner (1965) is acknowledged to have paved the major way for academic research in the theory of asset pricing. After 52 years, the model still proves its usefulness in solving many practical issues such as measuring the risk premium, estimating the cost of equity, and managing a diversified portfolio. As written by Fama and French (2004), the appeal of CAPM offers a powerful prediction and intuitively satisfies on how to measure the risk and relationship between expected return and risk.

The existing literatures suggest that a number of ideas have been proposed by the contemporary financial experts to improve CAPM. The first idea focuses on the development of domestic CAPM by proposing additional risk factors, such as company size, liquidity, information and the other factors of relevant price. Furthermore, due to the wave of financial liberalization and stock market internalization in the early 1970s, Solnik (1974b) and Adler and Dumas (1983) downgrade the theoretical version of ICAPM 
that assumes a hypothesis of perfect integration. This model proposes that similar assets have the same price regardless of the market where these assets are traded.

Adler and Dumas (1983) state that one of the methods used to show the potential for risk reduction contains regression of individual stock or national market index return on the world market index return. This is a pathway (phase) taken by Solnik (1974a) and Lessard (1976). In Lessard's experiment, regression residuals of national stock index or local industry index on a proxy of world market index is introduced as an additional orthogonal factor in testing the market model.

Mishra and O'Brien (2001) suggest the difference of equation between local CAPM and global CAPM. Traditional CAPM states that the cost of equity can be estimated as the risk-free rate of interest plus an adjustment for risk, which equals the equity's beta multiplied by the market portfolio risk premium. The relationship in the context of the local (domestic) market is expressed as follows:

$$
\mathrm{E}\left(\mathrm{R}_{\mathrm{i}}\right)=\mathrm{r}_{0}+\beta_{\mathrm{iL}}\left[\mathrm{E}\left(\mathrm{R}_{\mathrm{L}}\right)-\mathrm{r}_{0}\right]
$$

Where $\mathrm{E}\left(\mathrm{R}_{\mathrm{i}}\right)$ : expected return (cost of equity) for company $\mathrm{i} ; \mathrm{r}_{0}$ : risk free rate; $\beta_{\mathrm{iL}}$ : beta of company i's equity against the local market index returns; $\mathrm{E}\left(\mathrm{R}_{\mathrm{L}}\right)$ : equilibrium expected rate of return on the local market index.

Eq. 4 with the domestic market index is suitable only in companies whose shares are traded in the closed national financial market. If the purchasing power parity (PPP) condition holds, then the international asset pricing theory (Adler \& Dumas, 1983; Solnik, 1974b) simplifies into single-factor global CAPM. The single-factor global CAPM is shown in Eq. 5 as follows:

$$
\mathrm{E}\left(\mathrm{R}_{\mathrm{i}}\right)=\mathrm{r}_{0}+\beta_{\mathrm{iG}}\left[\mathrm{E}\left(\mathrm{R}_{\mathrm{G}}\right)-\mathrm{r}_{0}\right]
$$

Where $E\left(R_{i}\right)$ : expected return (cost of equity) for company $i$; $r_{0}$ : risk free rate; $\beta_{i G}$ : beta of company i's equity against the global market index returns; $\mathrm{E}\left(\mathrm{R}_{\mathrm{G}}\right)$ : equilibrium expected rate of return on the global market index.

Koedijk et al. (2002) and Bruner et al. (2008) investigate the sensitivity of individual stock returns on the home country and global indices for different stock markets and in different periods by implementing domestic CAPM and International CAPM. They find varying evidence and conclude that the choice of which model better fits the data, the domestic CAPM using the home country index or the International CAPM using global index, depends on the level of global market integration.

\section{METHODOLOGY}

This paper observed eight stock markets in China, Indonesia, Japan, Malaysia, Philippines, Singapore, Thailand, and the United Kingdom. Daily stock prices of constituent companies of all eight stock markets in the sample are obtained from bloomberg.com, yahoo.finance.com, wsj.com, stooq.com, and other websites contain relevant data. The sample period ranges from January 2003 to December 2016. In particular, the global financial crisis periods is identified as 03 May 2008 - 31 May 2009 by following Chiang and Zheng (2010) and Litimi et al. (2016).

The data set consist of the most liquid and larger market capitalization constituent stocks of the main indices in China (SSE-50), Indonesia (LQ-45), Japan (N-225), Malaysia (KLCI-30), Philippines (PSEi-30), Singapore (STI-30), Thailand (SET-50), and the United Kingdom (UK-100) stock markets. Daily returns for the constituent companies are calculated as follows: $\mathrm{R}_{\mathrm{it}}=\ln \left(\mathrm{P}_{\mathrm{t}}-\mathrm{P}_{\mathrm{t}-1}\right) \times 100$. The second data set contains eight market indices of the stock markets observed and the world market index, which is MSCI ACWI (Morgan Stanley Capital International All Countries World Index) as the proxy. These daily data of each stock exchange and world market indices are calculated to obtain local market returns and world market returns, respectively. They are utilized as components of Equations 6, 7,13 and 19. 
The purposes of this study are achieved by two stages that each stage consists of different method. The first stage attempts to determine the classification of a stock market whether it was categorized in integrated or segmented market. The analysis for this stage employs the International CAPM method. The second stage attempts to identify the presence of herding behavior on each stock market by considering the market classification as examined in the first stage. The analysis for this stage applies the standard CSAD model for segmented market and the international CSAD model for integrated market.

In this stage, we adopt the similar method worked by Arshad (2017), Bruner et al. (2008), and Koedijk et al. (2002) who applied International CAPM model to examine the level of integration of a stock market towards world stock market. The first step we estimate the local (national) CAPM for each stock market by working time series regressions of each individual stock return $\left(\mathrm{R}_{\mathrm{it}}\right)$ on its respective daily local market return $\left(\mathrm{R}_{\mathrm{mt}}\right)$ over the sample period expressed by the equation as follows:

$$
\mathrm{R}_{\mathrm{it}}=\alpha+\beta_{\mathrm{im}} \mathrm{R}_{\mathrm{mt}}+\varepsilon_{\mathrm{i}}
$$

Where $\mathrm{R}_{\mathrm{it}}$ is the ex post return on stock $\mathrm{i}$ at day $\mathrm{t} ; \mathrm{R}_{\mathrm{mt}}$ is the ex post return observed for local market at day $\mathrm{t} ; \beta_{\mathrm{im}}$ is local market beta of each firm i produced by time series regression of each individual stock returns on local market index return; $\varepsilon_{i}$ is error term.

The second step we run time series regressions of $R_{\text {it }}$ on a world market index $\left(R_{w t}\right)$ as follows:

$$
\mathrm{R}_{\mathrm{it}}=\alpha+\beta_{\mathrm{iw}} \mathrm{R}_{\mathrm{wt}}+\varepsilon_{\mathrm{i}}
$$

Where $\mathrm{R}_{\mathrm{wt}}$ is the returns on the world market index and $\beta_{\mathrm{iw}}$ is the beta on the world market index for stock i.

Combining the estimations of Eqs. 6 and 7 gives a panel of beta coefficients for local and world CAPM. The last, we estimate the cross-sectional regressions of the world beta on the local beta for all stocks in each stock market to measure the degree of integration using the equation as follows:

$$
\beta_{\text {iv }}=\alpha_{0}+\alpha_{1} \beta_{\text {im }}+\varepsilon
$$

The decision criteria for the degree of integration rely on the coefficient of determination $\left(\mathrm{R}^{2}\right)$ value from regression Eq. 8. The higher the $\mathrm{R}^{2}$, the better the fit between local and world market beta, that is, there is a higher degree of integration. Conversely, a lower $\mathrm{R}^{2}$ indicates segmented markets.

The varying methodologies have been presented in the literature of herding. One was based on the dispersion of returns among a set of securities that focuses on the standard deviation or absolute return. The previous studies using this methodology include Christie and Huang (1995) on US stocks, Chang et al. (2000) on international equities, Gleason et al. (2004) on commodities of futures markets on European exchanges, Demirer and Kutan (2006) and Tan et al. (2008) on stocks in China. Other testing methodology which is based on cross-sectional dispersion of the factor sensitivity of assets is proposed by Hwang and Salmon (2004). They analyze daily stock returns in the South Korean market and provide support for the formation of herding in the market. Furthermore, the earlier herding methodology than the abovementioned methodologies is proposed by Lakonishok et al. (1992).

Christie and Huang (1995) state CSSD (cross-sectional standard deviation of returns) as a proxy of herding behavior. Such behavior is covered by a negative sign of extreme market periods on the CSSD. The measure of CSSD is expressed as follows:

$$
\mathrm{CSSD}=\sqrt{\frac{\sum_{\mathrm{t}=1}^{\mathrm{N}}\left(\mathrm{R}_{\mathrm{i}, \mathrm{t}}-\mathrm{R}_{\mathrm{m}, \mathrm{t}}\right)^{2}}{\mathrm{~N}-1}}
$$

Where $\mathrm{R}_{\mathrm{i}, \mathrm{t}}$ is the observed stock returns on firm $\mathrm{i}$ at time $\mathrm{t} ; \mathrm{R}_{\mathrm{m}, \mathrm{t}}$ is the cross-sectional average stock of $\mathrm{N}$ returns in portfolio at time $\mathrm{t} ; \mathrm{N}$ is the number of firms in portfolio.

The model of CSSD is expressed as follows:

$$
\operatorname{CSSD}_{\mathrm{t}}=\alpha+\beta_{1} \mathrm{D}_{\mathrm{t}}^{\mathrm{L}}+\beta_{2} \mathrm{D}_{\mathrm{t}}^{\mathrm{U}}+\varepsilon_{\mathrm{t}}
$$


The positive sign on $\beta_{1}$ and $\beta_{2}$ in Eq. 10 indicates that there is no herding behaviour which is the rational asset pricing prevails.

The measure of CSSD has many limitations because it is only valid during the period of extreme movement and it does not apply because of the consideration of asymmetric assumption in the distribution of returns. In addition, many researches do not find evidence of herding using this measure or the result is inconsistent (Huang et al., 2015). Therefore, Chang et al. (2000) propose a more robust proxy of herding inspired by CAPM, that is cross-sectional absolute deviation of returns (CSAD). The formula of CSAD is expressed as follows:

$$
\operatorname{CSAD}=\frac{1}{\mathrm{~N}} \sum_{\mathrm{t}=1}^{\mathrm{N}}\left|\mathrm{R}_{\mathrm{i}, \mathrm{t}}-\mathrm{R}_{\mathrm{m}, \mathrm{t}}\right|
$$

Where CSAD is a measure of returns dispersion; $R_{i, t}$ is the realized returns on stock $i$ on time $t ; R_{m, t}$ is the average value of an equally weighted realized returns of all stock in portfolio at time $t$.

Litimi et al. (2016) suggest that the measure of CSAD is a proxy for herding, but it does not mean the presence of herding itself. CSAD is the average of the proximity of the individual returns to the average market return. The small value of CSAD indicates the possibility of a general consensus of investors to trade on certain stocks and a great value indicates the possibility of deviation.

The model of CSAD is expressed as follows:

$$
\operatorname{CSAD}_{\mathrm{t}}=\gamma_{0}+\gamma_{1}\left|\mathrm{R}_{\mathrm{m}, \mathrm{t}}\right|+\gamma_{2} \mathrm{R}_{\mathrm{m}, \mathrm{t}}^{2}+\varepsilon_{\mathrm{t}}
$$

Non-linearity relationship between CSAD and market returns squared is covered by $\gamma_{2}$. If herding occurs, then $\gamma_{2}$ is estimated to be significantly negative (Economou et al., 2011). Concave quadratic function of CSAD shows why $\gamma_{2}$ should be negative, because CSAD reaches its highest value when $R_{m, t}^{*}=-\gamma_{1} / 2 \gamma_{2}$.

In the literature on herding behaviour of individual stocks towards market consensus, previous studies can be grouped based on the role of foreign stock market involvement. The first group only detects domestic herding behaviour without including the role of foreign stock market, such as Chang et al. (2000). The model they propose is expressed as follows:

$$
\operatorname{CSAD}_{\mathrm{t}}=\gamma_{0}+\gamma_{1}\left|\mathrm{R}_{\mathrm{m}, \mathrm{t}}\right|+\gamma_{2} \mathrm{R}_{\mathrm{m}, \mathrm{t}}^{2}+\varepsilon_{\mathrm{t}}
$$

Where $\operatorname{CSAD}_{t}$ is the cross-sectional absolute deviation of returns at time $t ;\left|R_{m, t}\right|$ is the absolute returns of domestic market index at time $t ; \mathrm{R}_{\mathrm{m}, \mathrm{t}}^{2}$ is the return of domestic market index squared at time $\mathrm{t}$.

The second group is the study with including the role of international stock market, such as Chiang and Zheng (2010); Economou et al. (2011); Mobarek et al. (2014); Galariotis et al. (2015). The model they propose is expressed as follows:

$$
\operatorname{CSAD}_{\mathrm{t}}=\gamma_{0}+\gamma_{1}\left|\mathrm{R}_{\mathrm{m}, \mathrm{t}}\right|+\gamma_{2} \mathrm{R}_{\mathrm{m}, \mathrm{t}}^{2}+\gamma_{3} \mathrm{R}_{\mathrm{f}, \mathrm{t}}^{2}+\varepsilon_{\mathrm{t}}
$$

Where $\mathrm{R}_{\mathrm{f}, \mathrm{t}}^{2}$ is the foreign market returns squared.

The studies of second group attemp to expand assessment of herding on the integrated stock markets, meaning that investors carry out herding on a stock market caused by the information coming from foreign stock market. Such information is reflected on the return of more advanced foreign stock markets or dominant stock markets in a particular region or globally.

Historically, the studies of herding in both groups rely on standard rational asset pricing model (Lintner, 1965; Sharpe, 1964). For this model, Pettit and Westerfield (1974) suggest the equation for the ex ante returns as follows:

$$
\mathrm{E}\left(\mathrm{R}_{\mathrm{it}}\right)=\alpha+\beta_{\mathrm{i}} \mathrm{E}\left(\mathrm{R}_{\mathrm{mt}}\right)+\varepsilon_{\mathrm{i}}
$$

Where $\mathrm{E}\left(\mathrm{R}_{\mathrm{it}}\right)$ is the unconditional expected return on asset i period t; $\mathrm{E}\left(\mathrm{R}_{\mathrm{mt}}\right)$ is expected return on a market portfolio period $t ; \beta_{i}$ is a coefficient which measures the response of $R_{i t}$ to $R_{m t} ; \beta_{i}=\operatorname{cov}\left(R_{i t}, R_{m t}\right) / v a r\left(R_{m t}\right)$. 
Furthermore, Pettit and Westerfield (1974) associate market model with ex post CAPM version which describes a linear relationship between the return of individual securities and the return on portfolio of all assets. They formulate an equation for the ex post returns as follows:

$$
\mathrm{R}_{\mathrm{it}}=\alpha+\beta_{\mathrm{i}} \mathrm{R}_{\mathrm{mt}}+\varepsilon_{\mathrm{i}}
$$

Where $\mathrm{R}_{\mathrm{it}}$ is the ex post return on asset $\mathrm{i}$ at period $\mathrm{t}$; $\mathrm{R}_{\mathrm{mt}}$ is the ex post return observed for market portfolio at period $\mathrm{t}$.

In the CAPM model, it is assumed that each of the stock market in the world is segmented, which means that only one risk factor that affects on the return of an asset, namely the return of the domestic stock market. Therefore, other factors included in the model are treated as additional variables. In the existing studies, the concept of stock market integration in the form of additional variables is suggested by squared returns on dominant foreign stock market as a proxy, such as the studies in the second group. However, because of the principle of parsimony and the arguments based on international CAPM and its assumptions, then the standard CAPM is less simple when it is applied in the herding model used to detect the existence of herding for an integrated stock market internationally.

Because of the weakness, the international CAPM by Solnik (1974b) and Merton (1980), according to our ideas, should be applied as the foundation for creating a new model of herding behavior. International CAPM is explained for example in the studies of Mishra and O'Brien (2001); Bruner et al. (2008); Arouri et al. (2012).

Single-factor global CAPM suggested by Mishra and O'Brien (2001) is expressed in Eq. 4. Whereas, global CAPM equation by Bruner et al. (2008) is expressed in the following form:

$$
\left(\mathrm{R}_{\mathrm{it}}-\mathrm{r}_{\mathrm{t}}\right)=\alpha_{\mathrm{i}}^{\mathrm{G}}+\beta_{\mathrm{i}}^{\mathrm{G}}\left(\mathrm{R}_{\mathrm{Gt}}-\mathrm{r}_{\mathrm{t}}\right)+\varepsilon_{\mathrm{it}}
$$

Where $R_{i t}$ is the return for security $i$; $r_{t}$ is the risk free rate; $R_{G}$ is the return for global index.

Perfectly integrated international CAPM (PIICAPM) equation stated by Arouri et al. (2012) for asset $\mathrm{i}$ is expressed as follows:

$$
E\left(R_{i}\right)-r=\beta_{i}\left(E\left(R_{w}\right)-r\right)
$$

Where $\mathrm{E}\left(\mathrm{R}_{\mathrm{i}}\right)$ is the expected return on stock $\mathrm{i}$; $\mathrm{r}$ is the risk free rate; $\mathrm{R}_{\mathrm{W}}$ is the return on world market; $\mathrm{E}\left(\mathrm{R}_{\mathrm{i}}\right)$ $-r$ is excess return.

By combining between the standard herding behaviour model and international CAPM model, we propose a model of international herding behaviour as follows:

$$
\operatorname{CSAD}_{\mathrm{t}}^{*}=\gamma_{0}+\gamma_{1}\left|\mathrm{R}_{\mathrm{w}, \mathrm{t}}\right|+\gamma_{2} \mathrm{R}_{\mathrm{w}, \mathrm{t}}^{2}+\varepsilon_{\mathrm{t}}
$$

Where $\operatorname{CSAD}_{\mathrm{t}}^{*}$ is international cross-sectional absolute deviation of return at time $\mathrm{t} ;\left|\mathrm{R}_{\mathrm{w}, \mathrm{t}}\right|$ is the absolute return of world market index at time $t ; \mathrm{R}_{\mathrm{w}, \mathrm{t}}^{2}$ is the return of world market index squared at time $\mathrm{t}$.

Based on the above explanation, we initiate a new model of herding behavior. International herding behavior is the herding behavior that occurs in a stock market whose assets are integrated with international stock market globally. The existence of international herding behavior can be detected with the modified standard CSAD model. By basing on the international CAPM, the standard CSAD model rooted from the CAPM can be turned into a model of international CSAD by replacing the local (domestic) stock market return with the international (world) stock market return.

The international herding behavior model is expected to be used as a technique to identify the presence of herding behavior in a stock market. Stock market in this model is assumed or required to be integrated with world stock market. This is in accordance with ICAPM assumption that the investors take their investment decisions on an individual asset by focusing on the information of international asset price movement which they took as a benchmark of market portfolio. The model is obtained from the searches of previous studies which are a synthesis of standard CAPM, international CAPM and standard herding model. 


\section{EMPIRICAL RESULTS AND DISCUSSION}

Table 1 presents the descriptive statistics of the daily market return for each of the eight stock markets with number of sample periods ranging from 3376 days for China to 3539 days for the UK stock market. It has different number of sample days due to the difference in trading day of each exchange. For all indices, the average returns in Indonesia stock market exhibits the highest value amount to 0.075 percent. In the same stock market, however, it is not followed by the highest standard deviation. In this context, it suggests that the higher the risk of securities, the higher its returns does not prevail. The highest standard deviation is found in China stock market (1.683). It means that the market participants faced the stocks that more fluctuate when investing in China compared to the other stock markets.

Table 1

Descriptive statistics of market returns $\left(\mathrm{R}_{\mathrm{m}}\right)$ for the eight stock markets

\begin{tabular}{|l|c|c|c|c|c|c|c|c|}
\hline & CN & ID & JP & MY & PL & SG & TH & UK \\
\hline Mean & 0.024 & 0.075 & 0.023 & 0.027 & 0.056 & 0.023 & 0.043 & 0.017 \\
\hline Std. dev & 1.683 & 1.351 & 1.535 & 0.739 & 1.279 & 1.104 & 1.262 & 1.165 \\
\hline Minimum & -9.256 & -10.954 & -12.111 & -9.979 & -13.089 & -8.696 & -10.099 & -9.266 \\
\hline Maximum & 9.034 & 7.623 & 13.235 & 4.259 & 9.365 & 7.531 & 7.549 & 9.384 \\
\hline N-days & 3376 & 3391 & 3433 & 3450 & 3430 & 3511 & 3418 & 3539 \\
\hline
\end{tabular}

This table reports the daily mean, standard deviation, and the minimum and maximum values of the market returns $\left(\mathrm{R}_{\mathrm{m}}\right.$ ) over the sample period for China (CN), Indonesia (ID), Japan (JP), Malaysia (MY), Philippines (PL), Singapore (SG), Thailand (TH), and The United Kingdom (UK) stock markets. It has different number of sample days due to the difference in trading day of each exchange.

On the other hand, the UK stock market has the lowest daily average returns amount to 0.017 percent. Similarly, this fact is not followed by the lowest standard deviation. Furthermore, Malaysia stock market has the lowest standard deviation signifying that stock returns gained in this market is more stable and the investors bear lower risk. In addition, the highest spread of returns is found in Japan market ranging from minimum value (-12.111 percent) to maximum value (13.235 percent). It indicates that Japan market experienced higher volatility because it had most extreme returns.

Table 2

Estimates of market integration applying International CAPM method

\begin{tabular}{|l|c|c|c|c|}
\hline Markets & Constant & Coefficient of $\beta_{\mathrm{w}}$ & Adj.-R Squared & Conclusion \\
\hline China & ${ }^{* *} 0.726$ & ${ }^{* *} 0.81$ & 0.18 & Segmented \\
\hline Indonesia & ${ }^{* * *} 0.349$ & ${ }^{* * * 1.26}$ & 0.73 & Integrated \\
\hline Japan & ${ }^{* * *} 0.210$ & ${ }^{* * * 1.13}$ & 0.92 & Integrated \\
\hline Malaysia & ${ }^{* * *} 0.399$ & ${ }^{* * *} 2.26$ & 0.89 & Integrated \\
\hline Philippines & ${ }^{* * *} 0.511$ & ${ }^{* * * 1.15}$ & 0.31 & Segmented \\
\hline Singapore & ${ }^{* *} 0.097$ & ${ }^{* * * 1.51}$ & 0.95 & Integrated \\
\hline Thailand & ${ }^{* * *} 0.244$ & ${ }^{* * * 1.53}$ & 0.85 & Integrated \\
\hline The UK & ${ }^{* * *} 0.172$ & ${ }^{* * *} 0.86$ & 0.99 & Integrated \\
\hline
\end{tabular}

This table contains estimates results from cross-sectional regression of equation: $\beta_{\mathrm{iw}}=\alpha_{0}+\alpha_{1} \beta_{\mathrm{im}}+\varepsilon$. The coefficient of determination (adjusted- $\mathrm{R}^{2}$ ) gained from this regression is used as a benchmark to decide the integration category of a stock market. If a stock market that consists of the analyzed shares has higher adjusted- $\mathrm{R}^{2}$, it will be grouped in integrated stock markets and vice versa. Where $\beta_{i w}$ is world beta of each firm generated by time 
series regression of each individual stock returns on world market index return; $\beta_{\text {im }}$ is local market beta of each firm produced by time series regression of each individual stock returns on local (national) market index return. The asterisks $(* * *, * *)$ indicate that $p$-value is significant respectively at the $1 \%, 5 \%, 10 \%$ level.

For subsequently analysis, the daily market returns of each stock exchange have role as an independent variable in time series manner against individual returns of each firm as expressed in Eq. 6. This process is worked to obtain individual beta of firm $\left(\beta_{\text {im }}\right)$, which is called as local (national) market beta. The second role of the data is employed as a main source to obtain the absolute market returns $\left|R_{m}\right|$ and the squared market returns $\mathrm{R}_{\mathrm{m}}^{2}$ as written in Eq. 13.

Results from cross-sectional regression of world market beta $\left(\beta_{\text {iw }}\right)$ on local market beta $\left(\beta_{\text {im }}\right)$ generate conclusions about integration of each market, which are presented in Table 2. It shows that China and Philippines are concluded as segmented stock markets. This relies on the magnitude of adjusted- $\mathrm{R}$ squared from the cross-sectional regressions. Both of these markets have lower adjusted-R squared, which are 18 percent and 31 percent, respectively. The equations of estimation for these markets are expressed as follow:

$$
\begin{array}{lll}
\beta_{\text {iw }}=* * * 0.726+* * 0.81 \beta_{\text {im }} & \text { Adj. }-\mathrm{R}^{2}=0.18 & \text { China } \\
\beta_{\text {iw }}=* * * 0.511+* * * 1.15 \beta_{\text {im }} & \text { Adj. }-\mathrm{R}^{2}=0.31 & \text { Philippines }
\end{array}
$$

The six remaining markets, namely Indonesia, Japan, Malaysia, Singapore, Thailand, and The UK, are classified as integrated stock markets since they had higher adjusted- $\mathrm{R}^{2}$ ranging from 73 percent for Indonesia to 99 percent for the UK. It had been examined in many researches that the developed stock markets such as The UK, Japan, and Singapore appeared prominent degree of integration towards world equity market. The equations of estimation ranked by adjusted- $\mathrm{R}^{2}$ values for the six integrated markets are expressed as follow:

$$
\begin{array}{lll}
\beta_{\text {iw }}=* * * 0.349+* * * 1.26 \beta_{\text {im }} & \text { Adj.- } \mathrm{R}^{2}=0.73 & \text { Indonesia } \\
\beta_{\text {iw }}=* * * 0.244+* * * 1.53 \beta_{\text {im }} & \text { Adj.- } \mathrm{R}^{2}=0.85 & \text { Thailand } \\
\beta_{\text {iw }}=* * * 0.399+* * * 2.26 \beta_{\text {im }} & \text { Adj.- } \mathrm{R}^{2}=0.89 & \text { Malaysia } \\
\beta_{\text {iw }}=* * * 0.210+* * * 1.13 \beta_{\text {im }} & \text { Adj.- } \mathrm{R}^{2}=0.92 & \text { Japan } \\
\beta_{\text {iw }}=* * 0.097+* * * 1.51 \beta_{\text {im }} & \text { Adj.- } \mathrm{R}^{2}=0.95 & \text { Singapore } \\
\beta_{\text {iw }}=* * * 0.172+* * * 0.86 \beta_{\text {im }} & \text { Adj.- } \mathrm{R}^{2}=0.99 & \text { The UK }
\end{array}
$$

According to the degree of integration analyzed above, the subsequent work is to detect the existence of herding within each stock market grouped. We observed that China and Philippines are grouped in segmented markets. The interesting evidence suggests that both of these markets have higher average CSAD as presented in Table 3. It also presents the summary statistics of CSAD values for all stock markets observed. The sample firms analyzed are only the active stocks in main indices of SSE-50, LQ-45, N-225, KLCI-30, PSEi-30, STI-30, SET-50, and UK-100 for each stock market. The number of firms selected ranges from 30 to 210 firms. The statistics presented in Table 3 show that the average CSAD is higher in Indonesia, Philippines, and China than for the others amount to 1.714, 1.423, and 1.381, respectively. The standard deviations of CSAD for China, Philippines, and Indonesia are higher as compared to other countries. Similarly, the spreads of CSAD for these countries are higher than for the others.

Indonesia stock market has the highest spread of CSAD, from minimum value (0.312) to maximum value (6.071), followed by spread of CSAD for China stock market. It means that Indonesia stock market experienced larger fluctuations of returns dispersion compared to the other markets. In contrast to Indonesia stock market, Malaysia has the lowest spread of CSAD from 0.225 to 3.058. In this context, the Indonesia, Philippines, and China stock markets have similar characteristics on the average CSAD, standard deviation of CSAD, and spread of CSAD. However, among these three markets as conveyed before only Indonesia was grouped in integrated markets. Such characteristics are possible as the signs for the presence of herding behavior in these markets by considering the type of market integration. 
Summary statistics of CSAD for the eight stock markets

\begin{tabular}{|l|c|c|c|c|c|c|c|c|}
\hline & CN & ID & JP & MY & PL & SG & TH & UK \\
\hline Mean & 1.381 & 1.714 & 1.233 & 0.892 & 1.423 & 1.069 & 1.323 & 0.998 \\
\hline Std. Dev & 0.670 & 0.636 & 0.430 & 0.336 & 0.530 & 0.440 & 0.412 & 0.455 \\
\hline Minimum & 0.301 & 0.312 & 0.487 & 0.225 & 0.411 & 0.301 & 0.522 & 0.307 \\
\hline Maximum & 5.711 & 6.071 & 4.367 & 3.058 & 4.767 & 4.429 & 4.129 & 4.306 \\
\hline N-firms & 30 & 41 & 210 & 30 & 30 & 30 & 34 & 50 \\
\hline
\end{tabular}

This table reports the daily mean, standard deviation, and the minimum and maximum values of the cross-sectional absolute deviation of returns (CSAD) over the sample period for China (CN), Indonesia (ID), Japan (JP), Malaysia

(MY), Philippines (PL), Singapore (SG), Thailand (TH), and The United Kingdom (UK) stock markets. The difference in number of sample firms is due to the elimination of the firms that have incomplete data of daily stock price.

Table 4 exhibits the estimate results of herding for all periods considering the type of market integration. The estimate equations for each market by running the non-linear regression are expressed as follow:

\begin{tabular}{|c|c|c|c|c|}
\hline $\mathrm{CSAD}_{\mathrm{t}}$ & $=* * * 1.052+* * * 0.3408\left|\mathrm{R}_{\mathrm{m}, \mathrm{t}}\right|$ & - & $* * * 0.02374 \mathrm{R}_{\mathrm{m}, \mathrm{t}}^{2}$ & China \\
\hline $\operatorname{CSAD}_{\mathrm{t}}$ & $=* * * 1.171+* * * 0.2925\left|\mathrm{R}_{\mathrm{m}, \mathrm{t}}\right|$ & - & $* * * 0.00922 \mathrm{R}_{\mathrm{m}, \mathrm{t}}^{2}$ & Philippines \\
\hline $\operatorname{CSAD}_{\mathrm{t}}^{*}$ & $=* * * 1.570+* * * 0.1925\left|\mathrm{R}_{\mathrm{W}, \mathrm{t}}\right|$ & + & $* 0.01207 \mathrm{R}_{\mathrm{w}, \mathrm{t}}^{2}$ & Indonesia \\
\hline $\operatorname{CSAD}_{\mathrm{t}}^{*}$ & $=* * * 1.087+* * * 0.2043\left|\mathrm{R}_{\mathrm{W}, \mathrm{t}}\right|$ & + & $0.00402 \mathrm{R}_{\mathrm{w}, \mathrm{t}}^{2}$ & Japan \\
\hline $\operatorname{CSAD}_{\mathrm{t}}^{*}$ & $=* * * 0.816+* * * 0.1118\left|\mathrm{R}_{\mathrm{w}, \mathrm{t}}\right|$ & - & $0.00069 \mathrm{R}_{\mathrm{w}, \mathrm{t}}^{2}$ & Malaysia \\
\hline $\mathrm{CSAD}_{\mathrm{t}}^{*}$ & $=* * * 0.934+* * * 0.1842\left|\mathrm{R}_{\mathrm{w}, \mathrm{t}}\right|$ & + & $* * 0.00868 \mathrm{R}_{\mathrm{w}, \mathrm{t}}^{2}$ & Singapore \\
\hline $\mathrm{CSAD}_{\mathrm{t}}^{*}$ & $=* * * 1.253+* * * 0.0827\left|\mathrm{R}_{\mathrm{W}, \mathrm{t}}\right|$ & + & $* * * 0.01231 \mathrm{R}_{\mathrm{w}, \mathrm{t}}^{2}$ & Thailand \\
\hline $\mathrm{CSAD}_{\mathrm{t}}^{*}$ & $=* * * 0.794+* * * 0.2811\left|\mathrm{R}_{\mathrm{w}, \mathrm{t}}\right|$ & + & $* * * 0.01138 \mathrm{R}_{\mathrm{W}, \mathrm{t}}^{2}$ & The UK \\
\hline
\end{tabular}

When the coefficients of $\gamma_{2}$ in the regression estimates are analyzed, the results suggest that the negative significant coefficients only appear on China and Philippines stock markets. These indicate that herding behavior was identified in both of these markets. Moreover, relating to findings as presented in Table 2 and Table 3 , it possible that herding behavior was more found in the stock markets having higher average CSAD and classified as segmented market. In contrast to that finding, there is no herding behavior in Indonesia, Japan, Malaysia, Singapore, Thailand and The UK markets. According to the evidences about presence of herding behavior, we argue that there is a different pattern between segmented and integrated markets. Hence, it can be stated that the herding behavior appears in a stock market when it was segmented, and vice versa.

It needs to explain what makes segmented markets different from integrated markets about the presence of herding. The characteristics of segmented stock markets are related to the inefficiency and the paucity of reliable micro- and international-information received by investors. Such markets can be improved by enhancing the quality of information disclosure required by market participants. In the presence of inefficient information disclosure, market participants will tend to lack fundamental information on firms and global markets, which may consequently cause them to trade based on other signals. Therefore, the differences in presence of herd behavior may be the result of degree of integration. 
Estimates of herding behaviour for all periods

\begin{tabular}{|c|c|c|c|c|c|c|}
\hline Markets & Constant & $\left|\mathrm{R}_{\mathrm{m}, \mathrm{t}}\right|$ & $\mathrm{R}_{\mathrm{m}, \mathrm{t}}^{2}$ & $\left|R_{w, t}\right|$ & $\mathrm{R}_{\mathrm{w}, \mathrm{t}}^{2}$ & Adj.- $R^{2}$ \\
\hline \multicolumn{7}{|c|}{ Model A: Segmented Stock Markets } \\
\hline China & $* * * 1.052$ & $* * * 0.3408$ & $* * *-0.02374$ & & & 0.17 \\
\hline Philippines & $* * * 1.171$ & $* * * 0.2841$ & $* *_{-} 0.00608$ & & & 0.18 \\
\hline \multicolumn{7}{|c|}{ Model B: Integrated Stock Markets } \\
\hline Indonesia & $* * * 1.570$ & & & $* * * 0.1925$ & $* 0.01207$ & 0.08 \\
\hline Japan & $* * * 1.087$ & & & $* * * 0.2043$ & 0.00402 & 0.17 \\
\hline Malaysia & $* * * 0.816$ & & & $* * * 0.1118$ & -0.00069 & 0.06 \\
\hline Singapore & $* * * 0.934$ & & & $* * * 0.1842$ & $* * 0.00868$ & 0.14 \\
\hline Thailand & $* * * 1.253$ & & & $* * * 0.0827$ & $* * * 0.01231$ & 0.06 \\
\hline The UK & $* * * 0.794$ & & & $* * * 0.2811$ & $* * * 0.01138$ & 0.29 \\
\hline
\end{tabular}

This table reports the estimated coefficients of the following regression models:

Model A for segmented stock markets: $\operatorname{CSAD}_{\mathrm{t}}=\gamma_{0}+\gamma_{1}\left|\mathrm{R}_{\mathrm{m}, \mathrm{t}}\right|+\gamma_{2} \mathrm{R}_{\mathrm{m}, \mathrm{t}}^{2}+\varepsilon_{\mathrm{t}}$

Model B for integrated stock markets: $\operatorname{CSAD}_{\mathrm{t}}^{*}=\gamma_{0}+\gamma_{1}\left|R_{\mathrm{w}, \mathrm{t}}\right|+\gamma_{2} R_{\mathrm{w}, \mathrm{t}}^{2}+\varepsilon_{\mathrm{t}}$

Where $\operatorname{CSAD}_{\mathrm{t}}$ is the cross-sectional absolute deviation of returns at day $\mathrm{t} ; \mathrm{R}_{\mathrm{m}, \mathrm{t}}$ is the return of domestic market index at day $\mathrm{t} ; \mathrm{R}_{\mathrm{m}, \mathrm{t}}^{2}$ is the return of domestic market index squared at day $\mathrm{t}$; $\operatorname{CSAD}_{\mathrm{t}}^{*}$ is the international cross-sectional absolute deviation of return at day $t ; R_{w, t}$ is the return of world market index at day $t ; R_{W, t}^{2}$ is the return of world market index squared at day t.

Chiang and Zheng (2010) inspired that integrated stock market, marked by higher technology of facilities and equipments, easier and faster information processing, and more efficient investment activity and trading, would be more opened against role of foreign stock markets globally. Bekaert and Harvey (1997) stated that the reinforcement against financial integration tends to improve degree of informational efficiency. When a stock market has highly degree of integration, it becomes more opened against all of the relevant information locally and globally. Hence, the investors can use the accurate and efficient information that lead to reduce dependence of the investors to make investment decisions from the others. Therefore, the herding more likely happened in a stock market when it was segmented.

Table 5

Estimates of herding behaviour for GFC periods

\begin{tabular}{|c|c|c|c|c|c|c|}
\hline Markets & Constant & $\left|R_{m, t}\right|$ & $\mathrm{R}_{\mathrm{m}, \mathrm{t}}^{2}$ & $\left|\mathrm{R}_{\mathrm{w}, \mathrm{t}}\right|$ & $\mathrm{R}_{\mathrm{w}, \mathrm{t}}^{2}$ & Adj. $R^{2}$ \\
\hline \multicolumn{7}{|c|}{ Model A: Segmented Stock Markets } \\
\hline China & $* * * 1.600$ & $* * * 0.2342$ & ***_-0.02606 & & & 0.06 \\
\hline Philippines & $* * * 1.514$ & $* * * 0.2897$ & $* *_{-} 0.01153$ & & & 0.22 \\
\hline \multicolumn{7}{|c|}{ Model B: Integrated Stock Markets } \\
\hline Indonesia & $* * * 1.954$ & & & $* * * 0.4190$ & $* *_{-} 0.03351$ & 0.15 \\
\hline Japan & $* * * 1.535$ & & & $* * * 0.3154$ & $* *_{-} 0.01548$ & 0.29 \\
\hline Malaysia & $* * * 1.109$ & & & $* * * 0.1390$ & $*_{-} 0.01138$ & 0.07 \\
\hline Singapore & $* * * 1.237$ & & & $* * * 0.4152$ & ****-0.03193 & 0.25 \\
\hline Thailand & $* * * 1.173$ & & & $* * * 0.2931$ & $*_{-} 0.01692$ & 0.26 \\
\hline The UK & $* * * 1.433$ & & & $* * * 0.3959$ & $*^{*} *_{-} 0.02345$ & 0.34 \\
\hline
\end{tabular}


This table reports the estimated coefficients of the regression models for both segmented and integrated stock markets during periods of global financial crisis which is identified as 03 May 2008 - 31 May 2009. The coefficient with $* * *, * *, *$ indicates significance value at the $1 \%, 5 \%$, and $10 \%$ level, respectively.

The existence of herding found in China stock market was in line with Chiang and Zheng (2010) and Lao and Singh (2011). In addition, similar finding of herding in Philippines stock market had been reported by Khan and Park (2009). The evidences found in this research compared to prior researches about herding behavior on each six remaining markets have different conclusion. It was more likely due to the difference in the methods, CSAD models, sample firms, and sample periods. For examples, in contrast to our findings, Chiang and Zheng (2010), using standard CSAD with sample period over 25 May 1988 to 24 April 2009, concluded that there are herding behavior in Indonesia, Japan, Malaysia, Singapore, Thailand, and the UK stock markets; Chang et al. (2000) found partial evidence of herding in Japan; and Galariotis et al. (2015) found no evidence of herding in the UK market.

We observed further the herding behaviour over global financial crisis period. Similar with the treatment of the non-linear regression models for all sample periods, these non-linear regressions were grouped into two models based on the type of market integration. The difference in sample period, however, exhibits different result. The estimate equations for each market during global financial crisis period are expressed as follow:

$\begin{array}{rlll}\operatorname{CSAD}_{\mathrm{t}} & =* * * 1.600+* * * 0.2342\left|\mathrm{R}_{\mathrm{m}, \mathrm{t}}\right|-{ }^{* * *} 0.02606 \mathrm{R}_{\mathrm{m}, \mathrm{t}}^{2} & \text { China } \\ \operatorname{CSAD}_{\mathrm{t}}=* * * 1.514+* * * 0.2897\left|\mathrm{R}_{\mathrm{m}, \mathrm{t}}\right|-{ }^{*} 0.01153 \mathrm{R}_{\mathrm{m}, \mathrm{t}}^{2} & \text { Philippines } \\ \operatorname{CSAD}_{\mathrm{t}}^{*}=* * * 1.954+* * * 0.4190\left|\mathrm{R}_{\mathrm{w}, \mathrm{t}}\right|-{ }^{*} 0.03351 \mathrm{R}_{\mathrm{w}, \mathrm{t}}^{2} & \text { Indonesia } \\ \operatorname{CSAD}_{\mathrm{t}}^{*}=* * * 1.535+* * * 0.3154\left|\mathrm{R}_{\mathrm{w}, \mathrm{t}}\right|-{ }^{*} 0.01548 \mathrm{R}_{\mathrm{w}, \mathrm{t}}^{2} & \text { Japan } \\ \operatorname{CSAD}_{\mathrm{t}}^{*}=* * * 1.109+* * * 0.1390\left|\mathrm{R}_{\mathrm{w}, \mathrm{t}}\right|-{ }^{*} 0.01138 \mathrm{R}_{\mathrm{w}, \mathrm{t}}^{2} & \text { Malaysia } \\ \operatorname{CSAD}_{\mathrm{t}}^{*}=* * * 1.237+* * * 0.4152\left|\mathrm{R}_{\mathrm{w}, \mathrm{t}}\right|-{ }^{* * *} 0.03193 \mathrm{R}_{\mathrm{w}, \mathrm{t}}^{2} & \text { Singapore } \\ \operatorname{CSAD}_{\mathrm{t}}^{*}=* * * 1.173+* * * 0.2931\left|\mathrm{R}_{\mathrm{w}, \mathrm{t}}\right|-{ }^{*} 0.01692 \mathrm{R}_{\mathrm{w}, \mathrm{t}}^{2} & \text { Thailand } \\ \operatorname{CSAD}_{\mathrm{t}}^{*}=* * * 1.433+* * * 0.3959\left|\mathrm{R}_{\mathrm{w}, \mathrm{t}}\right|-{ }^{* *} 0.02345 \mathrm{R}_{\mathrm{w}, \mathrm{t}}^{2} & \text { The UK }\end{array}$

Table 5 presents estimate results of herding behavior during global financial crisis period. The result suggests that there is evidence of herding behavior during this period for both segmented and integrated stock markets. One possible explanation is that due to global information processing, investors in each of the capital markets tend to follow the news and shape their investment strategy based on the decisions and actions of investors on Wall Street considered as the central in processing and spreading the information of global investment. Therefore, when investors in the global market believe that news from Wall Street has value and then they form a consensus on investment decisions, the herding formation appears (Chiang \& Zheng, 2010).

This finding supports the thought stated by Christie and Huang (1995) that herding behavior is more visible during market stress. Furthermore, Chiang and Zheng (2010) provided the evidence suggesting that the crisis becomes as a trigger on herding activity in origin country of crisis and hence causes to appear contagion effect that overspread to other countries. During the credit market crisis, the US market as an origin market of crisis appeared the presence of herding. Returns dispersion of stocks in this market was transmitted to the other markets over the world. For example, Galariotis et al. (2015) concluded that there is spillover effect of herding from the US to the UK stock market. In addition, Khan and Park (2009) found empirically the strong evidence of herding contagion in Thailand, Malaysia, Indonesia, Korea, and Philippines stock markets. According to their statements, the herding behavior found for all eight stock markets analyzed in our research was more likely caused by the contagion effect. 
In contrast to the existence of herding in segmented stock markets, herding on integrated stock markets only occurred during the global financial crisis. Indeed, the integrated stock market has more efficient information and faster information processing, and it comprise of skillful international investors. During the crisis period, however, this type of market is susceptible to spillover effect or contagion effect. There is a well established and extensive strand of the literature that examines contagion effects in the transmission of adverse economic and financial shocks across international markets (Economou et al., 2011). In addition, Phylaktis and Ravazzolo (2002) stated that financial markets are more integrated towards international financial movements making them more sensitive to external shocks. Economic events show that financial turmoil does not occur independently of a country.

\section{CONCLUSION}

All this time, herding behavior model of individual stocks against the market consensus uses benchmark derived from CAPM theory. CAPM assumes that a stock market is segmented. Yet, recent evidences indicate that most of the stock markets are integrated. The analysis and discussion in the previous section can be concluded that there is an alternative model that can be applied to detect the existence of herding behavior specifically for an integrated stock market globally. This herding behavior model is an extension of previous models that do not consider the fact that the current development of stock market tends to be integrated on the international asset price movement.

Adopting the International CAPM method to determine the degree of integration for eight stock markets observed, the results showed that China and Philippines were concluded as segmented stock markets. In addition, Indonesia, Japan, Malaysia, Singapore, Thailand, and The UK were classified as integrated stock markets. These results then provide the basis for identifying herding behavior in these two different market classes. Using the standard CSAD model for segmented stock markets, we conclude that there is herding behavior in the China and Philippines stock markets for both over all sample period and market crisis period. Furthermore, by applying the International CSAD model for integrated stock markets, we report that there is no herding behavior in Indonesia, Japan, Malaysia, Singapore, Thailand, and The UK stock markets, except during market crisis period.

There are many methods created to determine the integration classification for a stock market such as dynamic conditional correlation (DCC) model. The methods could be alternative choices to be utilized in the further paper. As far as our knowledge, difference in the method used in the context of market integration could possible to generate different conclusion and thereafter we should to choose the appropriate herding model. A number of studies have reported, as noted earlier in this paper, that herding behavior can exacerbate volatility returns and make market instability. Therefore, market participants need to pay more attention when they invest in the market where the existence of this behavior was identified. Understanding to the stocks that have such characteristic could avoid them from the additional risk. To support this implication and to extend this topic, further researches should to examine the effect of herding on returns volatility by considering the different class of market integration.

\section{REFERENCES}

Adler, M., \& Dumas, B. (1983). International Portfolio Choice and Corporation Finance: A Synthesis. The Journal of Finance, 38(3), 925-984.

Alchian, A. A. (1950). Uncertainty, Evolution, and Economic Theory. The Journal of Political Economy, 58(3), 211-221.

Arouri, M. E. H., Nguyen, D. K., \& Pukthuanthong, K. (2012). An international CAPM for partially integrated markets: Theory and empirical evidence. Journal of Banking \& Finance, 36, 2473-2493. doi: 10.1016/j.jbankfin.2012.05.004 
Arshad, S. (2017). Stock Markets in Islamic Countries: An Inquiry into Volatility, Efficiency and Integration. Switzerland: Palgrave CIBFR Studies in Islamic Finance.

Baddeley, M. (2010). Herding, social influence and economic decision-making: socio-psychological and neuroscientific analyses. Philos Trans R Soc Lond B Biol Sci, 365(1538), 281-290. doi: 10.1098/rstb.2009.0169

Banerjee, A. V. (1992). A Simple Model of Herd Behavior. The Quarterly Journal of Economics, 107(3), 797-817.

Bekaert, G., \& Harvey, C. R. (1997). Emerging equity market volatility. Journal of Financial Economics, 43, 29-77. doi: 10.1016/S0304-405X(96)00889-6

Bikhchandani, S., Hirshleifer, D., \& Welch, I. (1992). A Theory of Fads, Fashion, Custom, and Cultural Change as Informational Cascades. Journal of Political Economy, 100(5), 992-1026.

Blasco, N., Corredor, P., \& Ferreruela, S. (2012). Does herding affect volatility? Implications for the Spanish stock market. Quantitative Finance, 12(2), 311-327. doi: 10.1080/14697688.2010.516766

Bruner, R. F., Li, W., Kritzman, M., Myrgren, S., \& Page, S. (2008). Market integration in developed and emerging markets: Evidence from the CAPM. Emerging Markets Review, 9, 89-103. doi: 10.1016/j.ememar.2008.02.002

Brunnermeier, M. K. (2001). Asset pricing under asymmetric information: bubbles, crashes, technical analysis, and herding. New York.: Oxford University Press Inc.

Chang, E. C., Cheng, J. W., \& Khorana, A. (2000). An Examination of Herd Behavior in Equity Markets: An International Perspective. Journal of Banking \& Finance, 24, 1651-1679.

Chiang, T. C., \& Zheng, D. (2010). An empirical analysis of herd behavior in global stock markets. Journal of Banking \& Finance, 34(8), 1911-1921. doi: 10.1016/j.jbankfin.2009.12.014

Chien, M.-S., Lee, C.-C., Hu, T.-C., \& Hu, H.-T. (2015). Dynamic Asian stock market convergence: Evidence from dynamic cointegration analysis among China and ASEAN-5. Economic Modelling, 51, 84-98. doi: 10.1016/j.econmod.2015.06.024

Christie, W. G., \& Huang, R. D. (1995). Following the Pied Piper: Do Individual Return Herd Around the Market? Financial Analysts Journal, 51(4), 31-37. doi: 10.2469/faj.v51.n4.1918

Click, R. W., \& Plummer, M. G. (2005). Stock market integration in ASEAN after the Asian financial crisis. Journal of Asian Economics, 16(1), 5-28. doi: 10.1016/j.asieco.2004.11.018

Demirer, R., \& Kutan, A. M. (2006). Does herding behavior exist in Chinese stock markets? Journal of International Financial Markets, Institutions and Money, 16(2), 123-142. doi: 10.1016/j.intfin.2005.01.002

Devenow, A., \& Welch, I. (1996). Rational Herding in Financial Economics. European Economic Review, 40(3-5), 603615.

Di Guilmi, C., He, X.-Z., \& Li, K. (2014). Herding, trend chasing and market volatility. Journal of Economic Dynamics and Control, 48, 349-373. doi: 10.1016/j.jedc.2014.07.008

Diamandis, P. F. (2008). Financial liberalization and changes in the dynamic behaviour of emerging market volatility: Evidence from four Latin American equity markets. Research in International Business and Finance, 22(3), 362377. doi: 10.1016/j.ribaf.2008.02.004

Economou, F., Kostakis, A., \& Philippas, N. (2011). Cross-country effects in herding behaviour: Evidence from four south European markets. Journal of International Financial Markets, Institutions and Money, 21 (3), 443-460. doi: 10.1016/j.intfin.2011.01.005

Fama, E. F., \& French, K. R. (2004). The Capital Asset Pricing Model: Theory and Evidence. Journal of Economic Perspectives, 18(3), 25-46.

Galariotis, E. C., Rong, W., \& Spyrou, S. I. (2015). Herding on fundamental information: A comparative study. Journal of Banking \& Finance, 50, 589-598. doi: 10.1016/j.jbankfin.2014.03.014

Gleason, K. C., Mathur, I., \& Peterson, M. A. (2004). Analysis of intraday herding behavior among the sector ETFs. Journal of Empirical Finance, 11(5), 681-694. doi: 10.1016/j.jempfin.2003.06.003

Harvey, C. R. (1991). The World Price of Covariance Risk. The Journal of Finance, 46(1), 111-157. doi: 10.2307/2328691

Hirshleifer, D., \& Teoh, S. H. (2003). Herd behaviour and cascading in capital markets: a review and synthesis. European Financial Management, 9(1), 25-66.

Huang, T.-C., Lin, B.-H., \& Yang, T.-H. (2015). Herd behavior and idiosyncratic volatility. Journal of Business Research, 68(4), 763-770. doi: 10.1016/j.jbusres.2014.11.025

Hwang, S., \& Salmon, M. (2004). Market stress and herding. Journal of Empirical Finance, 11(4), 585-616. doi: 10.1016/j.jempfin.2004.04.003

Khan, S., \& Park, K. W. (2009). Contagion in the stock markets: The Asian financial crisis revisited. Journal of Asian Economics, 20(5), 561-569. doi: 10.1016/j.asieco.2009.07.001

Koedijk, K. G., Kool, C. J. M., Schotman, P. C., \& Dijk, M. A. v. (2002). The cost of capital in international financial markets: local or global? Journal of International Money and Finance, 21, 905-929. doi: 10.1016/S02615606(02)00028-1

Lakonishok, J., Shleifer, A., \& Vishny, R. W. (1992). The Impact of Institutional Trading on Stock Price. Journal of Financial Economics, 32, 23-43. 
Lam, K. S. K., \& Qiao, Z. (2015). Herding and fundamental factors: The Hong Kong experience. Pacific-Basin Finance Journal, 32, 160-188. doi: 10.1016/j.pacfin.2014.11.002

Lao, P., \& Singh, H. (2011). Herding behaviour in the Chinese and Indian stock markets. Journal of Asian Economics, 22(6), 495-506. doi: 10.1016/j.asieco.2011.08.001

Lessard, D. R. (1976). World, Country, and Industry Relationships in Equity Returns: Implications for Risk Reduction through International Diversification. Financial Analysts Journal, 32(1), 32-38. doi: 10.2469/ faj.v32.n1.32

Lintner, J. (1965). The Valuation of Risk Assets and the Selection of Risky Investments in Stock Portfolios and Capital Budgets. The Review of Economics and Statistics, 47(1), 13-37.

Litimi, H., BenSaïda, A., \& Bouraoui, O. (2016). Herding and excessive risk in the American stock market: A sectoral analysis. Research in International Business and Finance, 38, 6-21. doi: 10.1016/j.ribaf.2016.03.008

Merton, R. C. (1980). On estimating the expected return on the market: an exploratory investigation. Journal of Financial Economics, 8, 323-361.

Messis, P., \& Zapranis, A. (2014). Herding behaviour and volatility in the Athens Stock Exchange. The Journal of Risk Finance, 15(5), 572-590. doi: 10.1108/JRF-04-2014-0054

Mishra, D. R., \& O'Brien, T. J. (2001). A comparison of cost of equity estimates of local and global CAPMs. The Financial Review, 36, 27-48.

Mobarek, A., Mollah, S., \& Keasey, K. (2014). A cross-country analysis of herd behavior in Europe. Journal of International Financial Markets, Institutions and Money, 32, 107-127. doi: 10.1016/j.intfin.2014.05.008

Mossin, J. (1966). Equilibrium in a Capital Asset Market. Econometrica, 34(4), 768-783.

Neaime, S. (2012). The global financial crisis, financial linkages and correlations in returns and volatilities in emerging MENA stock markets. Emerging Markets Review, 13(3), 268-282. doi: 10.1016/j.ememar.2012.01.006

Pettit, R. R., \& Westerfield, R. (1974). Using the capital asset pricing model and the market model to predict security returns. Journal of Financial and Quantitative Analysis, 9(4), 579-605.

Phylaktis, K., \& Ravazzolo, F. (2002). Measuring financial and economic integration with equity prices in emerging markets. Journal of International Money and Finance, 21, 879-903. doi: 10.1016/S0261-5606(02)00027-X

Pietrzak, M. B., Fałdziński, M., Balcerzak, A. P., Meluzín, T., \& Zinecker, M. (2017). Short-term Shocks and Longterm Relationships of Interdependencies Among Central European Capital Markets. Economics and Sociology, 10(1), 61-77. doi: 10.14254/2071-789X.2017/10-1/5

Ross, S. A. (1976). The Arbitrage Theory of Capital Asset Pricing. Journal of Economic Theory, 13, 341-360.

Sharpe, W. F. (1964). Capital Asset Prices: A Theory of Market Equilibrium under Conditions of Risk. The Journal of Finance, 19(3), 425-442.

Shiller, R. J. (1995). Conversation, information, and herd behavior. The American Economic Review, 85(2), 181-185.

Shleifer, A. (2000). Inefficient market: an introduction to behavioral finance. New York.: Oxford University Press Inc.

Solnik, B. H. (1974a). Why Not Diversify Internationally Rather than Domestically? Financial Analysts Journal, 30(4), 48-52. doi: 10.2469/faj.v51.n1.1864

Solnik, B. H. (1974b). An equilibrium model of the international capital market. Journal of Economic Theory, 8, 500-524.

Stulz, R. H. M. (1981). A model of international asset pricing. Journal of Financial Economics, 9, 383-406.

Tan, L., Chiang, T. C., Mason, J. R., \& Nelling, E. (2008). Herding behavior in Chinese stock markets: An examination of A and B shares. Pacific-Basin Finance Journal, 16(1-2), 61-77. doi: 10.1016/j.pacfin.2007.04.004

Venezia, I., Nashikkar, A., \& Shapira, Z. (2011). Firm specific and macro herding by professional and amateur investors and their effects on market volatility. Journal of Banking \& Finance, 35(7), 1599-1609. doi: 10.1016/j.jbankfin.2010.11.015

Welch, I. (2000). Herding among security analyst. Journal of Financial Economics, 52, 369-396.

World-Bank. (2017). Market capitalization of listed domestic companies. Retrievied October, 31, 2017, from https://data.worldbank.org/indicator/CM.MKT.LCAP.CD. 